\title{
Effect of two commercial preparations containing different GnRH analogues with dopamine antagonists on barbel Barbus barbus (L.) sperm quantity and quality
}

\author{
Beata Irena Cejko • Daniel Żarski • Sylwia Judycka • Dariusz Kucharczyk • \\ Beata Sarosiek • Radosław Kajetan Kowalski
}

Received: 4 February 2013/Accepted: 13 June 2013/Published online: 28 June 2013

(C) The Author(s) 2013. This article is published with open access at Springerlink.com

\begin{abstract}
The effectiveness of applying Ovaprim [(D-Arg ${ }^{6}$, Pro $\left.{ }^{9} \mathrm{NEt}\right)$-sGnRH + domperidone] and Ovopel [(D-Ala $\left.{ }^{6}, \mathrm{Pro}^{9} \mathrm{NEt}\right)-\mathrm{mGnRH}+$ metoclopramide] to male barbel Barbus barbus (L.) 6, 12 and $24 \mathrm{~h}$ after hormonal stimulation was analyzed. The control group (Control) during each time interval was stimulated with $0.9 \% \mathrm{NaCl}$. Milt was collected from seven fish only once $(n=7)$ for Ovopel, Ovaprim and Control group in order to determine total volume of milt, volume of milt per $\mathrm{kg}$ of body weight, sperm concentration, total sperm production, seminal plasma osmotic pressure, $\mathrm{pH}$ of milt and $\mathrm{pH}$ of seminal plasma. Woynarovich's solution $(68 \mathrm{mM} \mathrm{NaCl}+50 \mathrm{mM}$ urea) with the addition of $0.5 \%$ BSA ( $\mathrm{pH} 7.7 ; 181 \mathrm{mOsm} \mathrm{kg}^{-1}$ ) was used as the activating liquid. Selected parameters of sperm motility (MOT \%) and progressively motile sperm (\%), curvilinear velocity (VCL, $\left.\mu \mathrm{m} \mathrm{s}^{-1}\right)$, straight-line velocity $\left(\mu \mathrm{m} \mathrm{s}^{-1}\right)$, movement linearity $(\%)$, wobbling index $(\%)$, amplitude of lateral head displacement $(\mu \mathrm{m})$ and beat cross frequency $(\mathrm{Hz})$ were determined using the Computer-assisted sperm analysis system. A time of $6 \mathrm{~h}$ proved to be too short to obtain milt from barbel following hormonal stimulation with Ovaprim and Ovopel. Extending the time to $12 \mathrm{~h}$, however, resulted in $100 \%$ spermiation in males, regardless of hormonal preparation used for stimulation. The stimulation of spermiation in barbel is best performed using Ovopel $12 \mathrm{~h}$ upon application. Extending the latency period to $24 \mathrm{~h}$ following the application of this preparation results in a significant decrease in the volume of milt obtained, sperm count and motility parameters, including MOT and VCL, which may influence sperm fertilization ability.
\end{abstract}

B. I. Cejko $(\bowtie) \cdot$ S. Judycka · B. Sarosiek · R. K. Kowalski

Department of Gamete and Embryo Biology, Institute of Animal Reproduction and Food Research, Polish Academy of Sciences ul., Bydgoska 7, 10-243 Olsztyn, Poland

e-mail: b.cejko@pan.olsztyn.pl

D. Żarski · D. Kucharczyk

Department of Lake and River Fisheries, Faculty of Environmental Sciences, University of Warmia and Mazury, Olsztyn, Poland 
Keywords Barbel $\cdot$ Barbus barbus $(\mathrm{L}.) \cdot$ Sperm $\cdot$ mGnRHa $\cdot$ sGnRHa $\cdot$ CASA

\section{Introduction}

Conservation aquaculture is a very important tool for the restitution and support of fish species which are in danger of extinction (Philippart 1995; Ross et al. 2008). As a result, over the recent years, there has been increased interest in research aimed at devising effective procedures for producing high quality larvae and fry fish of endangered species (Targońska et al. 2010; Żarski et al. 2011). Barbel Barbus barbus (L.), the local population of which has been drastically reduced due to increased pollution of the aquatic environment, has a noteworthy position among these species (Penaz et al. 2003; Penczak et al. 2004). One of the main problems in the production of barbel larvae for stocking purposes is the low effectiveness of wild fish reproduction, i.e., reproduction of fish captured from open waters (Targońska et al. 2011). It is sometimes necessary to raise broodstocks of barbel under controlled conditions, in the case of much higher reproductive efficiency when compared to wild fish (Policar et al. 2010).

The most important aspect of controlled fish reproduction is the obtaining of highquality eggs and milt (Bobe and Labbe 2010; Rurangwa et al. 2004). On the other hand, the quality of gametes under controlled conditions is determined by the preparation used for hormonal stimulation, which is necessary for obtaining gametes of sufficient quantity and quality (Rurangwa et al. 2004; Kowalski et al. 2012). Successful hormonal stimulation of rheophilic fish of the Cyprinidae family has been performed using mainly gonadoliberin analogues (LHRH) or gonadoliberin analogues applied as a complex with a dopamine receptor antagonist, such as Ovopel or Ovaprim (Żarski et al. 2009; Cejko et al. 2011, 2012a). One Ovopel pellet contains 18-20 $\mu \mathrm{g}$ mammalian mGnRHa [D-Ala ${ }^{6}$, Pro ${ }^{9} \mathrm{NEt}$ ] and 8-10 mg metoclopramide (Horváth et al. 1997), while Ovaprim (available in the form of an oily liquid) contains $20 \mu \mathrm{g} \mathrm{m}^{-1}$ salmon sGnRHa [D-Arg ${ }^{6}$, Pro ${ }^{9} \mathrm{NEt}$ ] and $10 \mathrm{mg} \mathrm{ml}^{-1}$ domperidone (Peter et al. 1993). The existing research has confirmed a high efficiency of ovulation and economic profitability of artificial spawning among barbel bred in captivity under controlled conditions following the application of Ovopel and Ovaprim (Hakuć-Błażowska et al. 2010; Targońska et al. 2011).

Research on the hormonal stimulation of male barbels has so far been focused on assessing the effectiveness of applying Ovopel and Ovaprim in relation to the percentage of motile sperm (in a subjective method) and their concentration in milt (Targońska et al. 2011). The optimal time (between 12 and $136 \mathrm{~h}$ ) for obtaining milt from barbels was determined to be the latency period $12 \mathrm{~h}$ after Ovopel treatment (Cejko et al. 2012b). There is, however, a lack of detailed data regarding how commercial hormonal preparations other than Ovopel influence parameters determine the quantity and quality of milt which can significantly influence the fertilizing efficiency of fish eggs (Gage et al. 2004).

In the presented research, an attempt was made to show (a) if the time of milt collection from barbels can be shortened from 12 to $6 \mathrm{~h}$ following hormonal stimulation without a significant detrimental effect on its quality, (b) if the type of hormonal preparation (Ovaprim or Ovopel) and time of milt collection (6, 12 and 24 h) after its application significantly influences an increase/decrease in milt volume, sperm count, $\mathrm{pH}$ of milt and seminal plasma parameters and (c) if the type of hormonal preparation and time of milt collection has a significant influence on sperm motility parameters determined using Computer-assisted sperm analysis (CASA) system. 


\section{Materials and methods}

Origin of fish and hormonal treatment

Male barbels $(n=63)$ were derived from the Department of River and Lake Fisheries of the University of Warmia and Mazury in Olsztyn, where they had been bred and raised to the age of $4+$. The fish were kept in a closed-circuit pool with a capacity of 1,000 1 (pH: 7.2-7.8; oxygen content: $90 \%$ ) that was equipped with a thermoregulation system (Kujawa et al. 1999). Prior to the commencement of the studies, the males were acclimated to a temperature of $17{ }^{\circ} \mathrm{C}$ over a period of a couple days. After the initial adaptation period, the fish were marked and forty-two males were subjected to hormonal stimulation with two different hormonal preparations such as Ovaprim $(n=21)$ and Ovopel $(n=21)$. The control group $(n=21)$ was composed of fish which had been injected with $0.9 \% \mathrm{NaCl}$. The applied doses presented in Table 1 were equal to doses which are considered standard in the reproduction of rheophilic fish of the Cyprinidae family (Kucharczyk et al. 2008). Males with an average body weight and body length (LT) were used in the studies, and these were, respectively, determined to be $107.6 \pm 31.4 \mathrm{~g}$ and $23.5 \pm 2.3 \mathrm{~cm}$ for the control group, $95.3 \pm 22.3 \mathrm{~g}$ and $22.6 \pm 1.77 \mathrm{~cm}$ for the Ovaprim group and $99.2 \pm 44.5$ and $22.6 \pm 3.1 \mathrm{~cm}$ for the Ovopel group. Neither the body weight of the males nor their length statistically differed among the groups of fish. Following hormonal stimulation, water temperature was raised to $19-20{ }^{\circ} \mathrm{C}$ and maintained at a constant level for the remainder of the experiment.

Manipulation of spawners and milt collection

Milt was collected from all treated groups 6, 12 and $24 \mathrm{~h}$ following hormonal stimulation. At each time period, milt was collected from seven fish individually only once $(n=7)$, from each group of fish $(n=21)$. Before the collection of milt, the fish were weighed, their length measured and their abdomens dried in order to avoid possible contamination of milt with urine, feces or blood. The milt was collected by gentle abdominal massage of the male fish. All fish were manipulated under anesthesia using 2-phenoxyethanol with a $0.5 \mathrm{ml} \mathrm{l}^{-1}$ dose (Merck, Darmstadt, Germany).

Table 1 Selected preparations and their doses used to stimulate spermiation in barbel Barbus barbus (L.) males under controlled conditions

\begin{tabular}{|c|c|c|c|c|}
\hline Selected preparations & $\begin{array}{l}\text { Number of } \\
\text { fish }(N)\end{array}$ & $\begin{array}{l}\text { Commercial } \\
\text { name }\end{array}$ & Dose (b.w.) & Availability \\
\hline $0.9 \% \mathrm{NaCl}$ & 21 & Control & $1 \mathrm{ml} \mathrm{kg}^{-1}$ & $\begin{array}{l}\text { Sigma-Aldrich } \\
\text { (Germany) }\end{array}$ \\
\hline $\begin{array}{l}{\left[\left(\mathrm{D}-\mathrm{Arg}^{6}, \mathrm{Pro}^{9} \mathrm{NEt}\right)-\right.} \\
\text { sGnRH }+ \text { domperidone }]\end{array}$ & 21 & Ovaprim $^{\mathrm{a}}$ & $0.5 \mathrm{ml} \mathrm{kg}^{-1}$ & Syndel (Canada) \\
\hline $\begin{array}{l}{\left[\left(\mathrm{D}-\mathrm{Ala}^{6}, \mathrm{Pro}^{9} \mathrm{NEt}\right)-\right.} \\
\quad \text { mGnRH }+ \text { metoclopramide }]\end{array}$ & 21 & Ovopel $^{\text {b }}$ & 1 pellet $\mathrm{kg}^{-1}$ & $\begin{array}{l}\text { Unic-trade } \\
\text { (Hungary) }\end{array}$ \\
\hline
\end{tabular}

a $1 \mathrm{ml}$ of Ovaprim contained $20 \mu \mathrm{g}$ sGnRHa and $10 \mathrm{mg}$ domperidone (Peter et al. 1993)

b 1 pellet of Ovopel contained 18-20 $\mu \mathrm{g}$ mGnRHa and 8-10 mg metoclopramide (Horváth et al. 1997) 
Determination of milt volume and sperm count

The total volume of milt (TVM, ml) was measured directly after its collection using sterile syringes calibrated in $0.01-\mathrm{ml}$ increments. Before milt collection, the males were weighed $(\mathrm{kg})$ and together with the TVM values were used to calculate the volume of milt per $\mathrm{kg}$ of body weight (VOM, $\mathrm{ml} \mathrm{kg}^{-1}$ b.w.). The sperm concentration $\left(\times 10^{9} \mathrm{ml}^{-1}\right)$ was determined using the spectrophotometric method (Ciereszko and Dabrowski 1993) with prior dilution of the milt samples 1,000 times (in replicates) using $0.7 \% \mathrm{NaCl}$. Absorption of the samples was measured using a Beckman DU-640 spectrophotometer (Analytical Instruments, LLC, Golden Valley, MN, USA) at $\lambda=530 \mathrm{~nm}$. The results including mean of samples from each replicate were placed in the standard analytical curve formula $(y=107.28 x-0.2075$, where $x$ equals absorption measurement results) previously prepared for barbels using a Bürker chamber (cytometric method), and the concentration values were determined. The volume of milt and sperm concentration were used to calculate the total number of spermatozoa produced (TSP $\left.\times 10^{9}\right)$.

Determination of osmotic pressure and $\mathrm{pH}$ of seminal plasma

Seminal plasma was obtained by centrifuging milt twice (supernatant from first centrifugation was centrifuged again to ensure that no sperm cells are present in seminal plasma) at $10,000 \times g$ for $10 \mathrm{~min}$. The osmotic pressure of seminal plasma was measured using a Minitüb Abfüll-u. Labortechnik GmbH \&Co.KG apparatus (Tiefenbach, Germany). The $\mathrm{pH}$ of milt and $\mathrm{pH}$ of seminal plasma were determined using the Orion Star 3 meter equipped with an Orion Ross Ultra electrode (Thermo Scientific, MA, USA).

Determination of sperm motility using CASA system

The CASA system was used to determine selected parameters of sperm motility, i.e., the percentage of motile sperm (MOT, \%), progressively motile sperm (PRG, \%), curvilinear velocity (VCL, $\mu \mathrm{m} \mathrm{s}^{-1}$ ), straight-line velocity (VSL, $\mu \mathrm{m} \mathrm{s}^{-1}$ ), movement linearity (LIN, $\%$ ), wobbling index (WOB, \%), amplitude of lateral head displacement (ALH, $\mu \mathrm{m}$ ) and beat cross frequency $(\mathrm{BCF}, \mathrm{Hz})$. Sperm motility was activated in $25 \mu \mathrm{l}$ of Woynarovich solution containing $68 \mathrm{mM} \mathrm{NaCl}+50 \mathrm{mM}$ urea with the addition of $0.5 \% \mathrm{BSA}(\mathrm{pH}: 7.7$; osmolality: $181 \mathrm{mOsm} \mathrm{kg}{ }^{-1}$ ). Next, $1 \mu \mathrm{l}$ of the mixture of milt and activating fluid was placed on a Teflon-coated slide (12 wells of $30 \mu \mathrm{l}$ depth and 5-mm-diameter Teflon-coated slide glass, Tekdon, Inc., Myakka City, FA, USA). Approximately $6 \mathrm{~s}$ after movement activation, a recording of movement was initiated using a Basler a202K digital camera (Basler, Germany), integrated with an Olympus BX51 microscope (Plan FL N 20x/0,5 NH ph1 lens) (Olympus, Tokyo, Japan). Motility parameters of at least fifty tracks in each samples were used for the estimation of the mean CASA values. The recording speed was 46.6 frames per second, and 200 frames from each recording were analyzed using the CRISMAS program (Image House Ltd., Denmark). Sperm motility was measured twice (repeated) for each milt sample $(n=63)$ after which the average was taken from the two measurements in every group and for each of the analyzed CASA parameters. During CASA analysis, the milt samples were kept on ice $\left(+4{ }^{\circ} \mathrm{C}\right)$. 
Statistical analysis

The values of the volume of milt obtained (TVM and VOM), number of sperm (concentration and TSP), CASA parameters, seminal plasma osmotic pressure, $\mathrm{pH}$ of milt and $\mathrm{pH}$ of seminal plasma were characterized as mean and standard deviation $( \pm \mathrm{SD})$. In order to reveal differences in the values of the parameters between groups for a period of 12 or $24 \mathrm{~h}$, the Bonferroni post hoc test was used (two-way ANOVA, $\alpha=0.05$ ). The significance of differences in values of the analyzed parameters between the time of milt collection for a given group of fish was analyzed using the unpaired $t$ test with Welch's correction. Normal distribution was checked prior to statistical analysis, and percentage values (\%) were transformed using the arcsin function. Pearson's linear correlation was also performed between selected milt parameters. Statistical analysis was carried out using the GraphPad Prism program (GraphPad Software Inc., CA, USA).

\section{Results}

Spermiation success

After $6 \mathrm{~h}$, milt was obtained from one fish from the control group and one fish from the Ovopel group but was not collected from the Ovaprim group. After $12 \mathrm{~h}$, milt was obtained from $42.86 \%(n=3)$ of barbels from the control group and $100 \%$ of barbels stimulated with Ovaprim and Ovopel. After $24 \mathrm{~h}$, milt was obtained from $57.14 \%$ of males from the control $(n=4)$ and Ovopel groups, and from $87.71 \%(n=6)$ of males treated with Ovaprim.

Milt volume and sperm count

No significant differences in the TVM were observed between the groups of fish $12 \mathrm{~h}$ after hormonal treatment, whereas higher TVM values were noted $12 \mathrm{~h}$ after Ovaprim treatment $(7.19 \pm 0.54 \mathrm{ml})$ compared to the control group $(1.18 \pm 0.09 \mathrm{ml})(P<0.05)$. After $24 \mathrm{~h}$, a decrease in the TVM value was noted after Ovopel treatment compared to the values recorded after $12 \mathrm{~h}(P<0.05$, Fig. 1A). For VOM values, the influence of hormonal treatment turned out to be significant $12 \mathrm{~h}$ after Ovopel application $\left(10.21 \pm 4.05 \mathrm{ml} \mathrm{kg}^{-1}\right)$ in comparison with the control group $\left(3.36 \pm 1.18 \mathrm{ml} \mathrm{kg}^{1}\right)$ and $24 \mathrm{~h}$ after Ovaprim application $\left(7.19 \pm 4.84 \mathrm{ml} \mathrm{kg}^{-1}\right)$ in comparison with the control group $\left(1.95 \pm 0.88 \mathrm{ml} \mathrm{kg}^{-1}\right)$ $(P<0.05$, Fig. 1B). Significant differences were not observed in VOM values between the periods of milt collection (12 and $24 \mathrm{~h})$ for the individual groups $(P>0.05)$.

Significant differences were not found in sperm concentration either in the control group or in the group hormonally stimulated at 12 and $24 \mathrm{~h}$. After $12 \mathrm{~h}$, sperm concentration was found to be at $14.94 \pm 0.90 \times 10^{9} \mathrm{ml}^{-1}$ (Control), $13.36 \pm 3.50 \times 10^{9} \mathrm{ml}^{-1}$ (Ovaprim) and $12.29 \pm 3.02 \times 10^{9} \mathrm{ml}^{-1}$ (Ovopel), and after $24 \mathrm{~h}$, sperm concentration was found to be at $16.91 \pm 6.22 \times 10^{9} \mathrm{ml}^{-1}$ (Control), $10.99 \pm 5.41 \times 10^{9} \mathrm{ml}^{-1}$ (Ovaprim) and $10.08 \pm 6.36 \times 10^{9} \mathrm{ml}^{-1}$ (Ovopel). No differences were found in the sperm concentration between the periods of milt collection $(12$ and $24 \mathrm{~h})$ in the individual groups $(P>0.05$, Fig. 1C). After $24 \mathrm{~h}$ post-Ovopel treatment, a significant decrease in the total sperm production $(\mathrm{TSP})$ was recorded $\left(3.26 \pm 2.88 \times 10^{9}\right)$ compared to the values of these parameters recorded after $12 \mathrm{~h}\left(11.50 \pm 7.00 \times 10^{9}\right)(P<0.05$, Fig. 1D). 

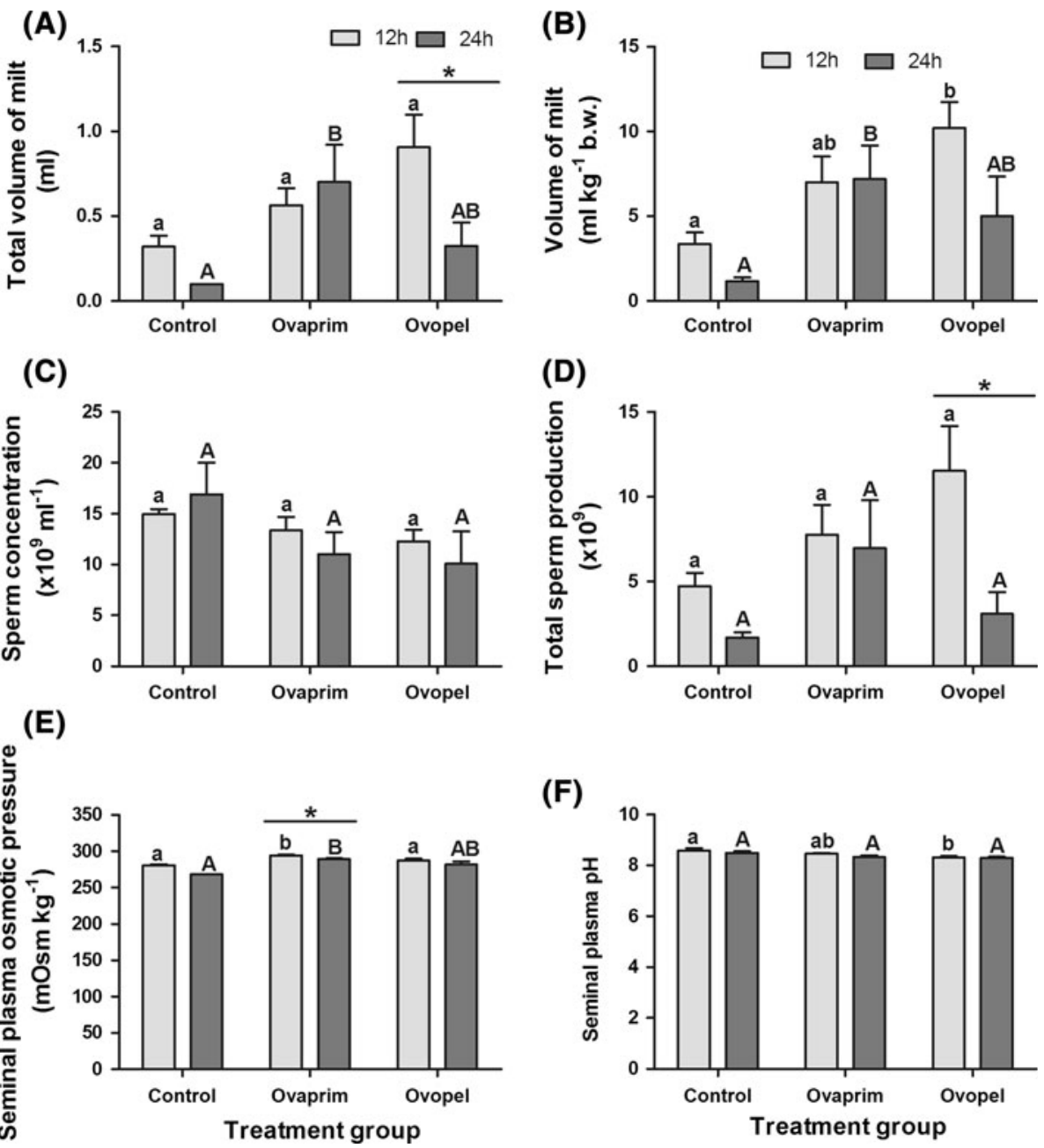

Fig. 1 Total volume of milt (A), volume of milt per $\mathrm{kg}$ of body weight $(\mathbf{B})$, sperm concentration $(\mathbf{C})$, total sperm production (D), seminal plasma osmotic pressure (E) and $\mathrm{pH}$ of seminal plasma (F) of barbel Barbus barbus (L.) 12 and $24 \mathrm{~h}$ after Ovopel and Ovaprim treatments and in the control group. Data marked with a different letter index between the groups differ significantly $(P<0.05)$. Lines with asterisk differ significantly within group between times of milt collection $(* P<0.05)$

Osmotic pressure and $\mathrm{pH}$ of seminal plasma

Seminal plasma osmotic pressure rose significantly 12 and $24 \mathrm{~h}$ after stimulation with Ovaprim (294.0 \pm 2.94 and $289.0 \pm 3.52 \mathrm{mOsm} \mathrm{kg}^{-1}$, respectively) in comparison with the control group $\left(280.5 \pm 2.12\right.$ and $268.0 \pm 3.31 \mathrm{mOsm} \mathrm{kg}^{-1}$, respectively $)(P<0.05)$. Compared to the control group, a similar increase was not noted after Ovopel treatment after either 12 or $24 \mathrm{~h}$ (Fig. 1E). Significant differences in seminal plasma osmotic pressure between the Ovaprim and Ovopel groups were noted only $12 \mathrm{~h}$ after hormonal treatment. The $\mathrm{pH}$ of seminal plasma was lowered only $12 \mathrm{~h}$ after Ovopel treatment $(8.31 \pm 0.15)$ as compared to the $\mathrm{pH}$ of seminal plasma recorded in the control group 
$(8.57 \pm 0.17$ ) (Fig. 1F; $P<0.05$ ). Significant differences in $\mathrm{pH}$ of seminal plasma between the periods of milt collection $(12$ and $24 \mathrm{~h})$ were not found for the individual groups $(P>0.05)$. Differences in the $\mathrm{pH}$ of milt were not found between the control, Ovaprim and Ovopel groups during the analyzed period of time (12 and $24 \mathrm{~h}$ ) and between the periods of milt collection for each given group (data not shown).

Sperm motility determined by CASA system

Hormonal stimulation did not have a significant influence on the CASA parameters, which were shown to be at a similar level at 12 and $24 \mathrm{~h}$ in hormonally stimulated groups as well as in the control group (Fig. 2A-H). A significant decrease $(P<0.05)$ in MOT and VCL values was, however, noted $24 \mathrm{~h}$ after Ovopel treatment $\left(90.6 \pm 11.8 \%\right.$ and $250.9 \pm 46.7 \mu \mathrm{m} \mathrm{s}^{-1}$, respectively) in comparison with these values recorded $12 \mathrm{~h}$ after treatment with this preparation $\left(96.4 \pm 2.91 \%\right.$ and $275.5 \pm 9.89 \mu \mathrm{m} \mathrm{s}^{-1}$, respectively) (Fig. 2A, C).

\section{Correlations}

After $12 \mathrm{~h}$, a positive correlation was observed between the volume of milt (VOM) and the total sperm production (TSP) after Ovopel (Table 2) and Ovaprim (Table 3) treatments. At this time, a significant negative correlation was observed between $\mathrm{pH}$ of seminal plasma and TVM (Ovopel and Ovaprim), VOM (Ovaprim) and TSP (Ovopel and Ovaprim). After $24 \mathrm{~h}$, a positive correlation was confirmed between values of TVM and VOM both after Ovopel (Table 4) and Ovaprim (Table 5) treatments. Moreover, the $\mathrm{pH}$ of seminal plasma correlated negatively with sperm concentration in the Ovaprim group (Table 5).

\section{Discussion}

This is the first study to show that spermiation stimulation of barbel can be conducted using a gonadoliberin analogue other than Ovopel, that is Ovaprim, and milt collection after Ovaprim application at a temperature of $19-20{ }^{\circ} \mathrm{C}$ can be extended to $24 \mathrm{~h}$ without quality losses. On the other hand, a period of $6 \mathrm{~h}$ after hormonal treatment is not sufficient to obtain barbel milt, regardless of the preparation used for hormonal application. The optimal time for obtaining barbel milt after Ovopel treatment is $12 \mathrm{~h}$, which has been confirmed by TVM and TSP values as well as MOT and VCL values taken from CASA analysis. It was confirmed that extending the time after Ovopel application to $24 \mathrm{~h}$ resulted in a significant decrease in the volume of milt, total sperm production and sperm motility parameters which may influence the efficiency of egg fertilization.

In many species, the availability of broodstock males, the proper conditions, health and maturity of which determine the amount and quality of gametes obtained under controlled conditions determines successful reproduction (Targońska and Kucharczyk 2011). Based on the percentage of females from which eggs are obtained, we can determine the usefulness of hormonal preparations used to stimulate and synchronize the ovulation of numerous fish species, including the rheophilic fish of the Cyprinidae family (Krejszeff et al. 2010; Targońska et al. 2010). In the case of barbel, for which in a controlled environment spontaneous ovulation is not observed (Policar et al. 2010), its synchronization is ensured by the application of hormonal preparations (Kouřil et al. 1988; Targońska et al. 2011). Hormonal preparations also determine the reproductive activity (spermiation) of males (Policar et al. 2010). The results of our study indicate that under 

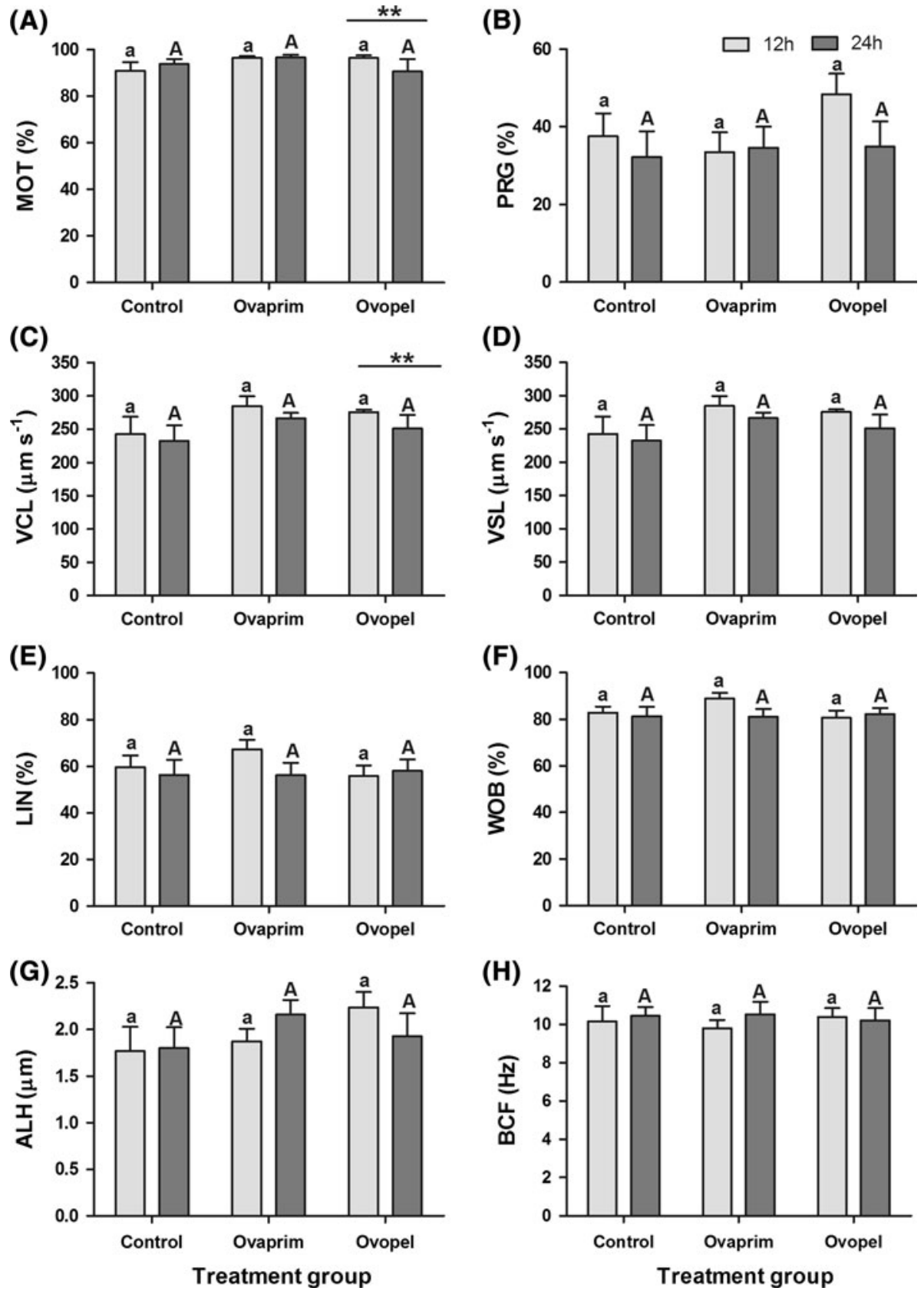

Fig. 2 The percentage of motile sperm (A), percentage of progressively motile sperm (B), curvilinear velocity $(\mathbf{C})$, straight-linear velocity $(\mathbf{D})$, movement linearity $(\mathbf{E})$, wobbling index $(\mathbf{F})$, amplitude of lateral head displacement $(\mathbf{G})$ and beat cross frequency $(\mathbf{H})$ of barbel Barbus barbus (L.) sperm, 12 and $24 \mathrm{~h}$ after Ovopel and Ovaprim treatments and in the control group. Data marked with the same letter index between the groups no differ significantly $(P>0.05)$. Lines with asterisks differ significantly within group between times of milt collection $(* * P<0.01)$ 
Table 2 Pearson's correlation coefficient between the parameters of milt collected from babel Barbus barbus (L.)

\begin{tabular}{lcllll}
\hline & TVM & VOM & $\begin{array}{l}\text { Sperm } \\
\text { concentration }\end{array}$ & TSP & $\begin{array}{l}\text { Seminal plasma } \\
\text { osmotic pressure }\end{array}$ \\
\hline VOM & $\mathbf{0 . 6 9 8} *$ & - & & & \\
Sperm concentration & 0.283 & $\mathbf{0 . 7 2 8 *}$ & - & & \\
TSP & $\mathbf{0 . 9 3 7 * * *}$ & $\mathbf{0 . 8 6 6 * *}$ & 0.584 & - & \\
$\begin{array}{l}\text { Seminal plasma osmotic } \\
\text { pressure }\end{array}$ & -0.074 & 0.553 & 0.639 & 0.182 & - \\
Seminal plasma pH & $\mathbf{- 0 . 8 7 4 * *}$ & -0.521 & -0.381 & $\mathbf{- 0 . 8 6 0 * *} 0.267$ \\
\hline
\end{tabular}

$12 \mathrm{~h}$ after $\left[\left(\mathrm{D}-\mathrm{Ala}^{6}\right.\right.$, Pro $\left.^{9} \mathrm{NEt}\right)-\mathrm{mGnRH}+$ metoclopramide $]$ i.e., Ovopel $(n=7)$ treatment

Bold values indicate significant correlations

$* P<0.05$

** $P<0.01$

*** $P<0.001$

Table 3 Pearson's correlation coefficient between the parameters of milt collected from babel Barbus barbus (L.)

\begin{tabular}{llllll}
\hline & TVM & VOM & $\begin{array}{l}\text { Sperm } \\
\text { concentration }\end{array}$ & TSP & $\begin{array}{l}\text { Seminal plasma } \\
\text { osmotic pressure }\end{array}$ \\
\hline VOM & $\mathbf{0 . 8 6 6 * *}$ & - & & & \\
Sperm concentration & 0.272 & 0.370 & - & & \\
TSP & $\mathbf{0 . 9 1 7 * *}$ & $\mathbf{0 . 8 8 9 * *}$ & 0.624 & - & \\
$\begin{array}{l}\text { Seminal plasma osmotic } \\
\text { pressure }\end{array}$ & -0.137 & 0.122 & -0.231 & -0.133 & - \\
Seminal plasma pH & $\mathbf{- 0 . 9 2 8 * *}$ & $\mathbf{- 0 . 9 6 2 * * *}$ & -0.196 & $\mathbf{- 0 . 8 5 8 * *}$ & -0.069 \\
\hline
\end{tabular}

$12 \mathrm{~h}$ after [(D-Arg $\left.{ }^{6}, \mathrm{Pro}^{9} \mathrm{NEt}\right)-\mathrm{sGnRH}+$ domperidone], i.e., Ovaprim $(n=7)$ treatment

Bold values indicate significant correlations

$* P<0.05$

$* * P<0.01$

$* * * P<0.001$

controlled conditions, spermiation of male barbels (similarly to ovulation in females) is determined by the time after hormonal treatment rather than the type of hormonal preparation used to induce this process. Shortening the time to $12 \mathrm{~h}$ after hormonal treatment was shown to be more beneficial (100\% spermiation in the Ovaprim and Ovopel groups) than extending it to $24 \mathrm{~h}$ (86 \% spermiation in the Ovaprim group and $57 \%$ spermiation in the Ovopel group).

The volume of milt and sperm production in Teleostei fish changes significantly over the period of the reproductive cycle, and these changes are determined mainly by environmental factors. In the case of barbel, differences in the volume of milt, sperm production and their motility have been found to be dependent on the period of the spawning season (Alavi et al. 2008a; Policar et al. 2011) as well as the time after hormonal treatment (Cejko et al. 2012b). The reproductive efficiency of male fish of the Cyprinidae family is determined by the application of complex preparations containing substances which have an antagonistic effect on dopamine receptors (metoclopramide and domperidone). The 
Table 4 Pearson's correlation coefficient between the parameters of milt collected from babel Barbus barbus (L.)

\begin{tabular}{lcclll}
\hline & TVM & VOM & $\begin{array}{l}\text { Sperm } \\
\text { concentration }\end{array}$ & TSP & $\begin{array}{l}\text { Seminal plasma } \\
\text { osmotic pressure }\end{array}$ \\
\hline VOM & $\mathbf{0 . 9 9 2 * *}$ & - & & & \\
Sperm concentration & -0.004 & -0.056 & - & & \\
$\begin{array}{l}\text { TSP } \\
\begin{array}{l}\text { Seminal plasma Osmotic } \\
\text { pressure }\end{array}\end{array}$ & 0.793 & 0.748 & 0.603 & - & \\
\begin{tabular}{l} 
Seminal plasma pH \\
\hline
\end{tabular} & -0.851 & -0.827 & 0.409 & -0.451 & n.d. \\
\hline
\end{tabular}

$24 \mathrm{~h}$ after [(D-Ala ${ }^{6}$, Pro $\left.^{9} \mathrm{NEt}\right)-\mathrm{mGnRH}+$ metoclopramide] i.e., Ovopel $(n=7)$ treatment

Bold values indicate significant correlations

n.d. $=$ no data

$* P<0.05$

** $P<0.01$

$* * * P<0.001$

Table 5 Pearson's correlation coefficient between the parameters of milt collected from babel Barbus barbus (L.)

\begin{tabular}{lrrlll}
\hline & TVM & VOM & $\begin{array}{l}\text { Sperm } \\
\text { concentration }\end{array}$ & TSP & $\begin{array}{l}\text { Seminal plasma } \\
\text { osmotic pressure }\end{array}$ \\
\hline VOM & $\mathbf{0 . 9 7 4 * * *}$ & \multicolumn{1}{c}{-} & & & \\
Sperm concentration & -0.309 & -0.313 & - & & \\
TSP & 0.638 & 0.696 & 0.434 & - & \\
Seminal plasma Osmotic pressure & 0.209 & 0.154 & 0.644 & 0.619 & - \\
Seminal plasma pH & 0.075 & 0.052 & $\mathbf{- 0 . 8 9 3 * *}$ & -0.556 & -0.549 \\
\hline
\end{tabular}

$24 \mathrm{~h}$ after [(D-Ala ${ }^{6}$, Pro $\left.^{9} \mathrm{NEt}\right)-\mathrm{mGnRH}+$ metoclopramide], i.e., Ovopel $(n=7)$ treatment

Bold values indicate significant correlations

$* P<0.05$

** $P<0.01$

$* * * P<0.001$

results of our study indicate the possibility of spermiation stimulating of barbel by applying not only Ovopel (Cejko et al. 2012b), but also Ovaprim. The application of both of these hormonal preparations (in commonly used doses) led to an increase in the reproductive efficiency of males when compared to the control group. However, the significant decrease in the volume of milt (TVM) and total sperm production (TSP) confirmed $24 \mathrm{~h}$ after Ovopel treatment indicates that the latency period in males of this species should be restricted to $12 \mathrm{~h}$.

Alavi et al. (2009a) reported that the most appropriate time for obtaining milt from barbels is the period during when osmolality of seminal plasma reaches a level of $290 \mathrm{mOsm} \mathrm{kg} \mathrm{kg}^{-1}$. The same authors also stated that an increase in the seminal plasma osmolality of barbel is accompanied by an increase in the volume of milt and total sperm production (Alavi et al. 2009b). On the other hand, our observations indicate that although there is no significant correlation between seminal plasma osmolality and the volume of milt or sperm count, there is a noticeable significant dependency of TVM and TSP values 
on $\mathrm{pH}$ of seminal plasma, which can be observed after Ovopel as well as Ovaprim treatment. The negative correlation observed $12 \mathrm{~h}$ after Ovopel treatment between $\mathrm{pH}$ of seminal plasma and TVM $(-0.874 ; P<0.01)$, as well as between $\mathrm{pH}$ of seminal plasma and TVM $(-0.928, P<0.01)$ and VOM $(-0.962 ; P<0.01)$ after Ovaprim treatment, indicates that along with an increase in the volume of milt, there is an observable decrease in the $\mathrm{pH}$ of seminal plasma. A significant negative correlation of seminal plasma $\mathrm{pH}$ with the volume of milt (TVM and VOM) and TSP was also observed in carp Cyprinus carpio L. $24 \mathrm{~h}$ after Ovopel treatment (Cejko, unpublished data). The differences observed in the $\mathrm{pH}$ values of seminal plasma between males subjected to Ovopel and the control group (12 h after stimulation) can signify the hydration of milt upon applying the males with exogenous hormones in the form of mGnRHa. It can be concluded that the gonadoliberin and metoclopramide complex sets off a cascade of physiological changes, leading to the release of endogenous hormones at the pituitary gland-gonadal axis. This leads to the maturation of milt and most likely also brings along a decrease in the sperm concentration while lowering the $\mathrm{pH}$ of seminal plasma.

Barbel sperm is considered to be "primitive" sperm, which is characteristic of most Cyprinidae fish (Alavi et al. 2008b). While the number of mitochondria and tail length of barbel sperm can be considered phylogenetic traits of the species (Alavi et al. 2008b), the parameters of motility are subject to numerous changes under precise conditions (Christ et al. 1996; Warnecke and Pluta 2003). Among the CASA parameters, particular attention should be directed to the percentage of MOT as well as the curvilinear velocity of sperm (VCL). The percentage of MOT is a determinant of quality based on which milt is assessed and, indirectly, the ability of egg fertilization. Many factors can influence motility, including hormonal stimulation, activating solution and time after the activation of sperm. It was confirmed that the stimulation of some Teleostei males with Ovopel results in a significant increase in MOT values when compared to the control group. A significant increase in MOT values in relation to the control group was also observed in the chub Leuciscus cephalus (L.), regardless of the applied hormonal preparation (Ovopel, Ovaprim, LHRHa or CPE) (Cejko et al. 2011), although a different activation solution was used ( $86 \mathrm{mM} \mathrm{NaCl})$ compared to the presented paper. This suggests the positive influence of hormonal stimulation on the sperm motility of Teleostei fish. Sperm velocity is a parameter which directly influences the ability of sperm to fertilize eggs (Gage et al. 2004). In Teleostei fish, sperm velocity (including the VCL and VSL parameters) assumes a wide range of values, which is most likely determined by the reproductive strategy of a given species. Importantly, sperm velocity as well as the percentage of MOT is subject to change under the influence of hormonal treatment which has been confirmed, among others in the common dace Leuciscus leuciscus (L.) (Cejko et al. 2012a). In the case of barbels, however, changes in VCL and VSL were not noted after stimulation with Ovopel and Ovaprim in relation to the control group, similarly to the lack of such a dependency in crucian carp Carassius carassius (L.) (Cejko et al. 2013). It is therefore possible that the dependency of sperm motility on hormonal stimulation is specific to the given species. Nevertheless, our observations indicate that $24 \mathrm{~h}$ after Ovopel treatment, the values of MOT as well as VCL of barbel sperm decrease significantly. This suggests a drop in sperm vigor accompanying the extension of the latency period beyond $12 \mathrm{~h}$ after the stimulation of fish.

One of the main factors determining the reproductive success of male barbels under controlled conditions is the latency period (measured in hours) that is the time from hormonal treatment to obtain milt of good quality. Spermiation in barbels should be stimulated using preparations containing GnRH analogues, enriched with dopamine receptor antagonists. Our observations indicate that spermiation stimulation of barbels is 
best performed using Ovopel in a period of $12 \mathrm{~h}$ after its application. Extending the time to $24 \mathrm{~h}$ after applying this preparation results in a significant decrease in the volume of milt, total sperm production and motility parameters such as MOT and VCL, which are important for the ability of sperm to successfully fertilize eggs.

Open Access This article is distributed under the terms of the Creative Commons Attribution License which permits any use, distribution, and reproduction in any medium, provided the original author(s) and the source are credited.

\section{References}

Alavi SMH, Pšenička M, Rodina M, Policar T, Linhart O (2008a) Changes of sperm morphology, volume, density and motility and seminal plasma composition in Barbus barbus (Teleostei: Cyprinidae) during the reproductive season. Aquat Living Resour 27:75-80

Alavi SMH, Pšenička M, Policar T, Linhart O (2008b) Morphology and fine structure of Barbus barbus (Teleostei: Cyprinidae) spermatozoa. J App Ichthyol 24:378-381

Alavi SMH, Pšenička M, Policar T, Rodina M, Hamáčkova J, Kozák P, Linhart O (2009a) Sperm quality in male Barbus barbus L. fed different diets during the spawning season. Fish Physiol Biochem 35:683-693

Alavi SMH, Rodina M, Policar T, Linhart O (2009b) Relationship between semen characteristics and body size in Barbus barbus L. (Teleostei: Cyprinidae) and effects of ions and osmolality on sperm motility. Comp Biochem Physiol Part A 153:430-437

Bobe J, Labbe C (2010) Egg and sperm quality in fish. Gen Com Endocrinol 165:535-548

Cejko BI, Krejszeff S, Żarski D, Targońska K, Kucharczyk D, Glogowski J (2011) The effectiveness of selected hormonal preparations in stimulating the spermation of the chub Leuciscus cephalus (L.). Pol J Nat Sci 26:235-245

Cejko BI, Targońska K, Kowalski RK, Żarski D, Sarosiek B, Kucharczyk D, Glogowski J (2012a) The effectiveness of hormonal preparations (Ovopel, Ovaprim, LHRHa, hCG and CPE) in stimulating spermiation in dace Leuciscus leuciscus (L.). J Appl Ichthyol 28:873-877

Cejko BI, Kowalski RK, Żarski D, Dryl K, Targońska K, Chwaluczyk R, Kucharczyk D, Glogowski J (2012b) The influence of the length of time after hormonal treatment with [(D-Ala ${ }^{6}$, Pro $\left.{ }^{9} \mathrm{NEt}\right)$ mGnRH + metoclopramide] i.e. Ovopel on barbel Barbus barbus (L.) milt quality and quantity indicators. J App Ichthyol 28:249-253

Cejko BI, Żarski D, Krejszeff S, Kucharczyk D, Kowalski RK (2013) Effect of hormonal stimulation of the crucian carp Carassius carassius (L.) on milt volume, number of sperm and its motility. Isr J Aquac Bamidgeh Accepted MS IJA_65.2013.912

Christ SA, Toth GP, McCarthy HW, Torsella JA, Smith MK (1996) Monthly variation in sperm motility in common carp assessed using computer-assisted sperm analysis (CASA). J Fish Biol 48:1210-1222

Ciereszko A, Dabrowski K (1993) Estimation of sperm concentration of rainbow trout, whitefish and yellow perch using a spectrophotometric technique. Aquaculture 109:367-373

Gage MJG, Macfarlance CP, Yeates S, Ward RG, Searle JB, Parker GA (2004) Spermatozoal traits and sperm competition in Atlantic salmon: relative sperm velocity is the primary determinant of fertilization success. Curr Biol 14:44-47

Hakuć-Błażowska A, Kupren K, Turkowski K, Targońska K, Żarski D, Kucharczyk D (2010) A comparison of the economic effectiveness of various spawning agents for stimulating the reproduction of the cultured and wild forms of the common barbel Barbus barbus (L.). Pol J Nat Sci 25:272-286

Horváth L, Szabó T, Burke J (1997) Hatchery testing of GnRH analogue-containing pellets on ovulation in four cyprinid species. Pol Arch Hydrobiol 44:221-226

Kouřil J, Filla V, Sandera K, Barth T, Flegel M (1988) Hormonally induced ovulation of common barbell (Barbus barbus L.) females by carp pituitary and LH-RH analogue. Bull VURH Vodnany 24:18-25

Kowalski RK, Hliwa P, Cejko BI, Król J, Stabiński R, Ciereszko A (2012) Quality and quantity of smelt (Osmerus eperlanus L.) sperm in relation to time after hormonal stimulation. Rep Biol 12:231-246

Krejszeff S, Targońska K, Żarski D, Kucharczyk D (2010) Artificial reproduction of two different spawnforms of the chub. Rep Biol 10(1):67-74

Kucharczyk D, Targońska K, Żarski D, Kujawa R, Mamcarz A (2008) A review of the reproduction biotechnology for fish from the genus Leuciscus. Arch Pol Fish 16:319-340

Kujawa R, Kucharczyk D, Mamcarz A (1999) A model system for keeping spawners of wild and domestic fish before artificial spawning. Aquacult Eng 20:85-89 
Penaz M, Pivnicka K, Barus F, Prokes M (2003) Temporal changes in the abundance of barbel, Barbus barbus in the Jihlava River, Czech Republic. Folia Zool 52(4):441-448

Penczak T, Galicka W, Głowacki Ł, Koszaliński H, Kruk A, Zięba G, Kostrzewa J, Marszał L (2004) Fish assemblage changes relative to environmental factors and time in the Warta River, Poland, and its oxbow lakes. J Fish Biol 64:483-501

Peter RE, Lin HR, van der Kraak G, Little M (1993) Releasing hormones, dopamine antagonists and induced spawning. In: Muir JP, Roberts RJ (eds) Recent advances in aquaculture. Institute of aquaculture, vol IV. Blackwell Scientific Publications, Oxford, pp 25-30

Philippart JC (1995) Is captive breeding an effective solution for the preservation of endemic species? Biol Conserv 72:281-295

Policar T, Podhorec P, Stejskal V, Hamackova J, Alavi SMH (2010) Fertilization and hatching rates and larval performance in captive common barbel (Barbus barbus L.) throughout the spawning season. J App Ichthyol 26:812-815

Policar T, Podhorec P, Stejskal V, Kozák P, Švinger V, Alavi SMH (2011) Growth and survival rates, puberty and fecundity in captive common barbel (Barbus barbus L.) under controlled condition. Czech J Anim Sci 56(10):433-442

Ross LG, Martinez Palacios CA, Morales EJ (2008) Developing native fish species for aquaculture, the interacting demands of biodiversity, sustainable aquaculture and livelihoods. Aquacult Res 39:675-683

Rurangwa E, Kime DE, Ollevier F, Nash JP (2004) The measurement of sperm motility and factors affecting sperm quality in cultured fish. Aquaculture 234:1-28

Targońska K, Kucharczyk D (2011) The application of hCG, CPH and Ovopel in successful artificial reproduction of goldfish (Carassius carassius auratus) under controlled conditions. Reprod Domest Anim 46:651-655

Targońska K, Kucharczyk D, Kujawa R, Mamcarz A, Żarski D (2010) Controlled reproduction of asp, Aspius aspius (L.) using luteinizing hormone releasing hormone (LHRH) analogues with dopamine inhibitors. Aquaculture 306:407-410

Targońska K, Kucharczyk D, Żarski D, Cejko BI, Krejszef S, Kupren K, Król R, Dryl K, Kowalski RK, Glogowski J (2011) Artificial reproduction of wild and cultured barbel (Barbus barbus, Cyprinidae) under controlled conditions. Acta Vet Hung 59:363-371

Warnecke D, Pluta HJ (2003) Motility and fertilizing capacity of frozen/thawed common carp (Cyprinus carpio L.) sperm using dimethyl-acetamide as the main cryoprotectant. Aquaculture 215:167-185

Żarski D, Kucharczyk D, Targońska K, Jamróz M, Krejszeff S, Mamcarz A (2009) Application of Ovopel and Ovaprim and their combinations in controlled reproduction of two rheophilic cyprinid fish species. Pol J Nat Sci 24:235-244

Żarski D, Kupren K, Targońska K, Krejszeff S, Furgała-Selezniow G, Kucharczyk D (2011) The effect of initial larval stocking density on growth and survival in common barbel Barbus barbus (L.). J Appl Ichthyol 27:1155-1158 